\title{
Gender positioning in the visual discourse of Algerian secondary education EFL textbooks: Critical image analysis vs teachers' perceptions
}

\author{
Ziad Khalid $^{\text {a* (D) , Ouahmiche Ghania }}{ }^{\text {b (iD }}$ \\ ${ }^{a}$ Mohamed ben Ahmed, PB 115 El-Mnaouer, Oran 31000, Algeria \\ ${ }^{b}$ Mohamed ben Ahmed, PB 115 El-Mnaouer, Oran 31000, Algeria
}

\section{APA Citation:}

Ziad, K., \& Ouahmiche, G. (2019). Gender positioning in the visual discourse of Algerian secondary education EFL textbooks: Critical image analysis vs teachers' perceptions. Journal of Language and Linguistic Studies, 15(3), 773-793.

Submission Date: 20/10/2018

Acceptance Date: 24/ 02/2019

\begin{abstract}
The present study revisits the issue of gender positioning within the visual discourse of three Algerian secondary education English textbooks. In order to get an informed view about gender representation in these materials, it was deemed necessary to combine the outcomes of theoretical critical accounts with language teachers' potential interpretations of gender bias within the textbooks. First, the selected visual corpus was scrutinized for gender bias through critical image analysis. The major aspects, in which gender bias can be embedded, have been addressed within a well-elaborated framework. Second, the perceptions that secondary education EFL teachers have of this issue were surveyed by dint of a self-report questionnaire which was submitted to a conveniently selected sample. The comparative analysis of the results indicate that while the majority of the images display clear signs of bias against females, most teachers hardly view any imbalances between the two genders as far as visual representation is concerned. This mismatch seems arguably related to the fact that gender bias is still considered a peripheral area of interest by the majority of EFL language practitioners.
\end{abstract}

(C) 2019 JLLS and the Authors - Published by JLLS.

Keywords: gender positioning; gender bias; visual discourse; EFL teachers' perceptions; ELT textbooks

\section{Introduction}

The issue of gender representation and role rose in prominence following the feminist movements which, according to Martiné (1986 p.11), "brought the concept of 'sexism' into use to denote discriminatory practices and ideologies against women". Since then, a large body of research has undertaken the analysis of language in its different varieties and multiple forms in order to find out about instances of sexism by which women were continually plagued (Lakoff, 1975). In their endeavor to eliminate sexist stereotypes and biased views, many researchers established guidelines and measures which were meant to result in more fairness and equity between the two sexes as far as language use is concerned. Although ideological differences had an immense bearing on the suggested guidelines (Mills \& Abolaji, 2015), most of the proposed changes helped in making some improvements in this regard.

\footnotetext{
* Ziad Khalid. Tel.: +213-540-536-144

E-mail address: khaledzd@yahoo.fr
} 
Perhaps, these calls for eradicating biased language and achieving equal representation of gender have never been louder than in academic institutions (UNFPA, 1994) which exert a far-reaching impact on individuals regardless of their age or sex. Of the many institutional aspects which are prone to sexism, teaching and learning materials have received much attention. In this perspective, textbooks have been thoroughly scrutinized to ascertain that females were not underrepresented or portrayed stereotypically. Due to the documentation of this problem in the overwhelming majority of the studies conducted, Blumberg (2008) reports that gender-biased textbooks seem to be a universal problem.

The central role that the textbook plays in the English as a foreign language (EFL) classroom made it an attractive area of investigating gender bias. Similar to the many sexist educational materials, most evaluated EFL textbooks have been found to be replete with apparent cases of sexism and stereotypes against women (Sunderland, 1992). The mounting concerns that this state of affairs could lead to females' stigmatization and marginalization have generated a large body of research which ultimately aims at the promulgation of gender fair materials. Evidently, the flagrant manifestations of sexism are hard to find in many current EFL textbooks; however, the yearning for egalitarian learning materials justifies the constant re-examination of this thorny issue that continues to create long-standing controversies in language teaching materials industry. One key area that still, we believe, needs appraisal is visual discourse which stands as a powerful tool for effective communication (Giaschi, 2000). In the process of making EFL textbooks, it is common practice to entrust the task of inserting visuals to publishers, who may unintentionally pay little heed to the guidelines of avoiding gender bias amidst their preoccupations with the textbooks space limitations or the acknowledgement of content copyrights. Given that much meaning is conveyed through images, photos, cartoons and illustrations, any visual misrepresentation of females and males might spoil the bias-free texts or distort the high values preached to students in the course of their learning experiences. Within this respect, the present study sets out to appraise gender positioning within the visual discourse of three English textbooks used in Algerian secondary education schools. Furthermore, it sheds light on EFL secondary teachers' perceptions of this issue. In contrast to the range and number of studies on content analyses for the detection of sexist language and stereotypes, studies about the meanings that textbooks users make from texts and images are relatively few.

\subsection{Literature review}

\subsubsection{Gender bias in EFL materials}

Although the principal purpose of the textbook in the EFL classroom is to provide opportunities for language learning and skills practice, it can serve as an ideal vehicle for the embodiment and transmission of moral values. As such, the textbook is far from being neutral in terms of the vision it conjures up or the world it depicts to its users (Littlejohn \& Windeatt, 1989). Early studies which embarked on gender bias in (English Language Teaching) ELT materials (Hartman \& Judd, 1978; Hellinger, 1980; Porreca, 1984) revealed a widespread discrimination in favour of males who were often dominant as characters, represented in a wider variety of social and occupational roles, and described as strong both physically and emotionally. Contrariwise, females were often less visible (if not excluded), described according to common traditional stereotypes and viewed as inferior and weak. In reporting this demeaning situation about females in a set of textbooks that she examined, Porreca (1984 p.712) writes that;

throughout the textbooks, stereotyped sex roles were rampant, including the overemotional female; housework and child care as female-exclusive domains; passive, weak female children; and active bold male children. Women were generally portrayed as selfish and superficial, while men were cast as helpful and patronizing. 
In effect, nearly a decade before Porreca's study, Schmitz (1975 cited in Graci, 1989) suggested that gender inequalities could be manifest in one of, or the following four categories: 'exclusion', 'subordination', 'distortion' and 'degradation'. The natural reaction to such biases and stereotypes had often been urgent appeals for making the necessary changes so as to render the textbooks more equitable and inclusive for both genders (women in EFL materials, 1991).

An important number of subsequent studies have pointed out to the continued existence of sexism within EFL instructional materials (Gupta \& Yin, 1990; Sakita, 1995; Renner, 1997; Ansari \& Babii, 2003), and small as well as significant improvements in terms of fairness and equity between males and females (Ma, 1998; Jones, Kitetu \& Sunderland, 1997; Cook, 2005; Mineshima, 2008). As Regards to these equivocal results, Blumberg (2008 p.17) contends that "the intensity of bias is diminishing, the most egregious and blatant examples of sexism seem to have disappeared or been muted even though the numbers certainly have not improved drastically". Actually, the recorded developments largely emanate from the internationally increased awareness of the importance of gender equality which augers well for women's education and empowerment (Gray, 2002). One viable way to track gender fairness in the learning materials is to revisit this issue after a relatively long span of time. Cook (2015) for example compared the status of gender imbalance within a current EFL textbook used in Japan with a previously analyzed textbook (Cook, 2005) for the same issue. Cook (2015) emphasizes that despite the substantial changes made, gender bias still lingers in the context of her study after a whole decade. Even though Cook's late report is just a small-scale, local study, it can serve as a good indication of how deeply sexism is entrenched within educational materials in general, and ELT materials in particular.

Gender misconceptions can be perpetuated through both manifest and subtle ways; unsurprisingly, the methods employed to detect them have been unsystematic and heterogeneous (Graci, 1989; Abolaji, 2013; Lee, 2014). Despite the diversity of methods, however, there has been a marked tendency within studies about gender bias to quantify language items, interpret language content or adopt both (Lesikin, 2001 p.276). For example, the quantitative analysis of texts and illustrations within textbooks has been widely used by researchers, most notably from 1970s up to the early 1990s (Sunderland, 2000). The rationale behind these content analyses had often been to check the distribution or visibility of females in comparison to males. In narratives, grammatical and lexical choices (such as the use of generic constructions, nouns and adjectives) were meticulously examined. The issues of firstness, as evidenced in the order of mentioning both genders, and dominance usually ensue from such considerations (Porreca, 1984). Equally important, the results of these analyses were utilized in demystifying male and female descriptions wherein stereotypes and restrictive roles can be embedded. This stance can even be extended to language as discourse. From this view, Sunderland (2000) elucidates that the analysis can be guided by raising the following questions; "What is the gender composition of the dialogues? Who speaks most in a mixed-sex dialogue? Who speaks first? What language functions do the males/females exemplify?" (Sunderland, 2000 p.85).

Certainly, the analysis of contents through quantified evidence can yield useful insights (Brugeilles \& Cromer, 2009); however, the inclusion of a qualitative interpretation would be far more illuminating (Jones et al, 1997) given that numbers can be misleading if considered out of their context. Qualitative analyses are conducted in the main within the framework of critical discourse analysis (CDA) which "aims to investigate critically social inequality as it is expressed, signalled, constituted, legitimized and so on by language use (or in discourse)" (Wodak, 2002 p.2). Through such a critical lens, it becomes much easier to discern gendered discourses (textual or visual) which, at first glance, might ostensibly look bias-free. On this basis, coupling quantitative and qualitative methods to scan gender positioning within EFL textbooks has become a modus operandi for many scholars (Ansari \& Babii, 2003; Levine and O'Sullivan, 2010; Mineshima, 2008; Kobia, 2009; Demir \& Yavuz, 2017). This trend seems to 
reflect the compelling need for research accountability concerning the inherent negative influence of biased materials on learners.

\subsubsection{The potential impact of sexist ELT materials on learners}

The probable impact of gender-biased materials on learners is a subject that has been dealt with extensively within the domain of education. The field of foreign language teaching was by no means an exception in this respect. Many researchers voiced their fears that such gender biases and injustices may well have insidious effects on the students "who generally attach great credibility and authority to educational materials, tend to absorb and assimilate the materials in minute detail without comment" (Lee \& Collins 2008, p.128). In her seminal study, Porreca (1984) warned that females' underrepresentation could implicitly be taken as an indication of their unworthiness. Similarly, Rifkin (1998 p.218) states that "the exclusion of girls and women from FL textbooks may seriously impair their abilities to understand the target language and its culture(s)". Although it is not easy to establish a causal relationship between the sexist materials and any following undesirable behaviours or attitudes (Sunderland, 2000), the majority of researchers substantiated their views by relying on the major role that the textbooks play as agents of socialization. With reference to this point, Sadker and Zittleman (2007 p.142) quote research which reports that "students spend as much as 80 to 95 percent of classroom time using textbooks, and teachers make a majority of their instructional decisions based on these texts". In such instructional environments, assimilating subliminal instances of sexism becomes very likely.

In spite of the fact that gender biases within textbooks represent a real source of worry, the critical engagement with the texts and visuals therein can stand as a proper safeguard against any indoctrination (Giaschi, 2000). Following this line of argument, Sunderland (2000 p.2) emphasizes the importance of avoiding "the pitfalls of representing teachers as predictable, willing, unquestioning textbook users, and of female learners as passive victims". These deterministic views can make combatting instances of sexism even more difficult. It is conceivable that the EFL classroom is usually full of enormous practical challenges to the teachers who may not take notice of sexism issues in the textbooks especially in their race against time to fulfil the mandatory teaching duties. Nonetheless, a complete lack of awareness of gendered discourses from the teachers, albeit unintentional, may render things worse in some teaching situations where, as Sunderland (2000) explains, the texts could be progressive but their exploitation is based on a sexist frame of mind. Bailey, Scantlebury and Letts (1997 p.32) elucidate that for this kind of teachers "gender inequity is the norm, and anything else is not normal". While Jones et al (1997) maintain that there will always be teachers who are indifferent to the pernicious nature of gender biases in language learning, Sadker (1999) attributes this lax attitude towards this issue to the absence of training in these important matters. In teacher training programmes, little attention seems to be directed to questions of educational equity and fairness. In fact, this view was reflected in a survey conducted by Aeginitou et al (as cited in Sunderland 2000). EFL teachers from different countries were asked about the role and importance of gender in language learning. Among different aspects of language teaching, it turned out that gender representation in teaching materials was the least that the surveyed teachers perceived as important.

\subsubsection{Current research on gender bias in the Algerian EFL textbooks}

Despite the distinguished position that the textbook occupies in the Algerian EFL curricula, there seems to be a dearth of studies in relation to gender bias in learning materials. It is true that the late educational reforms, initiated in 2003 , have led to a large textbook evaluation movement. However, the bulk of these investigations focused on the adequacy and successful implementation of the newly introduced teaching approach (competency-based approach) in the Algerian public schools (Zerar \& Riche, 2014), where English is taught to students for seven years as the second FL after French. 
After reviewing the available literature on this issue, only four relevant studies were found. To begin with, Abdelhay and Benhaddouche (2015) analyzed the illustrations within the first year middle school textbook (Spotlight on English 1) for gender bias. Departing from the significant role that illustrations play for young learners, the researchers conducted a content analysis according to three main categories: productive versus reproductive occupations, sport activities and frequency of appearances. The results of the study revealed the unfair as well as biased portrayal of females in the illustrations with reference to the three units of analysis: They were less visible, portrayed in traditional jobs and less apparent than their male counterparts in outdoor activities. Boukheddad (2011) examined the issues of gender, race and generation within the three secondary school English textbooks (At the Crossroads, Getting Through, and New Prospects). To guide her analysis of these learning materials, she relied on Sadker and Sadker's (1998) seven categories of bias (invisibility, stereotypes, linguistic bias, unreality, fragmentation, selectivity, and cosmetic bias). Moreover, she utilized a CDA framework in order to compensate for the subjective nature of content analysis. Across the three textbooks, the results indicated that females, minority groups and elders are underrepresented and portrayed stereotypically within texts and illustrations. A notable improvement, though, as reported in this study was the systematic use of inclusive words to refer to both genders.

Within a broader perspective, Lakhdar-Barka (2011) analyzed five English textbooks that were used successively by third year secondary school students between 1987 and 2007. Because over the span of these two decades the Algerian educational system has undertaken many changes, the author attempted to track and compare the status of female representation within the pictures and texts of these five textbooks. Opting for both a quantitative and qualitative methodology, she suggested that women's presence within these materials has been deteriorating despite the modest increase in the frequency of appearance, which does not reflect the actual place of Algerian women either in the workforce or in the public spheres. Taking a more comprehensive corpus, Boubakour (2017) conducted a large-scale analysis of 81 textbooks of all the subjects within the three curricula (primary, middle and secondary) in order to get a coherent picture of female representation and role in the current teaching materials. All the textbooks were quantitatively analyzed with reference to females' frequency of appearance as well as their social activities. This quantitative analysis was supported with a qualitative interpretation that shed light on the nature of themes developed in the texts. Similar to the majority of the analyzed textbooks, those of the English language were reported as being sexist and relatively biased as far as female description is concerned. By comparison with the other foreign language textbooks, the researcher claims that the ones devoted for English turned out to be the least displaying gender fairness and equity.

The corroborative evidence accumulated in the three last studies leaves no doubt over the existence of gender bias and sexism within secondary school EFL textbooks. Yet, we chose to reconsider this notorious issue within the same materials based on the following remarks. First, even though the aforementioned studies adopted both quantitative and qualitative methodologies, the latter did not seem to be well accounted for in comparison to the former. While the quantitative analyses were carried out in a detailed manner, the qualitative interpretation was made with little reference to a well-set theoretical framework. Second, discourse within these materials was evaluated as a monolithic block, with no sufficient consideration of the inherent distinctive characteristics of visual and written modes of expression. Perhaps this was due to the dominance of written discourse over the visuals to a point where these have become ancillary to texts. It is entirely legitimate to give precedence to written discourse within EFL textbooks, especially at an advanced level; however, visuals are also important in the EFL classroom since they can be used "as a springboard to help establish the topic, activate schemata and get students talking" (Donaghy \& Xerri, 2017 p. 3). Finally yet importantly, no attempt, to our knowledge, has been made in the context of the present study to explore the perspectives of these textbooks users 
on the issue of gender bias. It is believed that the inclusion of this dimension would result in a more balanced view about gender bias in instructional materials.

\subsection{Research questions}

The present study revolves around the exploration of gender positioning in the visual discourse (in all its forms) within the Algerian secondary school EFL textbooks, and the perspectives of teachers on this matter while using them. In pursuit of these two objectives, the following two questions were raised:

1. How is gender positioned within the visual discourse of the three secondary school EFL textbooks?

2. What are the perspectives of teachers on the existence of gender bias within these materials?

\section{Method}

\subsection{Analytical framework}

In response to the concerns raised about the evaluative instruments in the previous studies, the present research sets an explicit analytical framework for the qualitative analysis of gender representation and role within the visual discourse of the three textbooks. As indicated in the literature review, the quantification of content can produce revealing insights, however, the critical interpretation, through qualitative analysis, may well yield results that are far more illuminating. Grounded on the fundamental assumptions of CDA, Giaschi's (2000) analytical framework -critical image analysis- is adopted in our study. This framework consists of the following seven questions:

- What is the activity of the image(s)?

- Who is active (the "protagonist") in the image?

- Who is passive (the "receiver") in the image(s)?

- Who has status in the image(s)?

- What does the body language communicate?

- What does the clothing communicate?

- Where are the eyes directed?

Although some of the questions require just a straightforward answer, taken together they make a quantitatively structured and critical evaluation of gender portrayal in the images of materials. Of course, the subjective aspect of the interpretation is inescapable; however, the inquisitive nature of CDA forms the bedrock for deconstructing the complex realities and relationships of the modern life (Fairclough, 1989).

\subsection{Participants}

As our study addresses the EFL teachers' perceptions of gender positioning in visual discourse within the textbooks -whose use is often required in the classroom, it was deemed necessary to elicit this data from a conveniently chosen sample of EFL secondary school teachers. The sample is made up of 25 teachers who readily accepted to take part in this investigation. The participants were 7 males and 18 females. The majority of these teachers (22) have been teaching more than 5 years at the secondary school, which put them in a favourable position to have a say about the issue under investigation. 


\subsection{Materials and instruments}

The corpus of the current research is limited to the visual discourse within the three secondary education English textbooks (At the Crossroads, Getting Through and New Prospects). The latter make part of a new set of textbooks that were locally designed following the late educational reforms of 2003, which were nationally oriented. The three textbooks make together a series that reflects the secondary school English curriculum. Although the three textbooks are somehow different in terms of content organization and sequencing, they target the same language competencies: interaction, interpretation and language production. Because there are different editions of these materials, the present study selected the most recent edition of the three textbooks (2017).

The teacher questionnaire was developed by the researchers. To avoid the inherent limitations of this instrument, the questionnaire was initially piloted with three EFL secondary school teachers who did not make part of our sample. Based on their answers, a final version of this questionnaire was produced. The first 9 items, which together make up part one and two, targeted participants' background information as well as their use and evaluation of the textbooks. In the subsequent 9 items (which make up part 3), the respondents were asked to report on a five-point Likert scale the extent of their (dis)agreement with the statements about gender bias in the visual discourse of the textbooks. The fourth part of the questionnaire contains one item that solicited further comments from the respondents. The internal consistency of the items in part 3 can be considered high given that the calculated Cronbach Alpha of reliability is .91 .

\subsection{Data analysis}

As suggested in the literature review, there is a prevailing trend towards the use of both quantitative and qualitative methodologies in the investigation of gender bias within educational spheres, especially teaching and learning materials. An important aspect of this orientation is that it allows for a far more insightful interpretation of the data. Although the framework adopted in our study seems closer to qualitative analysis, it involves some inevitable quantification given that the study deals with many pictures. In addition, this framework is, according to Giaschi, tailored to shed light on images figuring both males and females within the materials. The appearance of both sexes together makes the rapport between them more apparent, which results in a more in-depth analysis (Giaschi, 2000). Based on this view, our selection of the images was made in compliance with two criteria. First, only images presenting both females and males will be counted; second; the size of the image should be large enough for the characters depicted therein to be noticed with relative ease.

After the numerical coding of the results collected from the teacher questionnaire, these data were entered in SPPS (20) for statistical analysis. Given that nearly all the items in the questionnaire are closed questions, the counting of responses was straightforward. As for the likert scale items, the strongly agree option was assigned 5 points and the strongly disagree 1 point. The neutral option was a midpoint position; thus, it was accorded 3 points. The main aim behind this analysis is to generate descriptive frequencies which can mirror the overall trends and patterns with regard to the teachers' critical use of textbooks as well as their awareness of gender bias within the visual discourse in these materials. 


\section{Results}

\subsection{Critical image analysis}

Although the three textbooks contain approximately 220 visual images (photos and cartoon comic strips) that display human characters, only 30 have been analysed, which represents nearly $14 \%$ of the entire targeted visual discourse. The exclusion of the remainder was due either to the fact that the visual does not present both genders together (170 images, 77\%), or to the difficulty of identifying the gender of characters in the visuals (20 images, 9\%). It is worth mentioning, in this respect, that a set of juxtaposed photos in a collage were regarded as a single image (For example images 1, 3 and 21 in the appendix). More details about the selected images are shown in table 1.

Table 1. Number of females and males within the images of the three textbooks

\begin{tabular}{cccc}
\hline Textbook & $n$ of images & $n$ of females & $n$ of males \\
\hline At the Crossroads & 11 & 16 & 20 \\
Getting Through & 5 & 8 & 14 \\
New Prospects & 14 & 24 & 30 \\
\hline
\end{tabular}

From the results in table 1 , we can clearly notice that notwithstanding the relatively small number of images presenting both genders together in the three textbooks, females still suffer from low visibility in comparison to males within this type of visual discourse. To discern how strong this bias is within our corpus, the images were subjected to scrutiny through the following questions:

\subsubsection{What is the activity of the image(s)?}

The principal activity within the analyzed images has to do with studies and research. 10 images (33.33\%) depict both males and females interacting about a school-related subject, studying in a university library or using a computer. The focus on social life is also clear given that 8 images $(26.66 \%)$ portray both genders in various social situations and events such as parties, ceremonies and taking public transport. Work is described in 5 images (16.66\%), and family life is present is 4 images (13.33\%). These are followed by natural disasters in 2 images $(06.66 \%)$ and sport in 1 image $(3.33 \%)$. The distribution of these activities between females and males is shown in table 2 .

Table 2. The distribution of activities within the images according to gender

\begin{tabular}{ccc}
\hline Activity & $n$ of females & $n$ of males \\
\hline Studies and research & 12 & 14 \\
Social life & 12 & 18 \\
Family life & 4 & 4 \\
Work & 10 & 17 \\
Sport & 6 & 7 \\
Natural disasters & 4 & 3 \\
\hline
\end{tabular}

The analysis of the images for this question reveals that both males and females take part in different activities which are all related to teenagers' interests and immediate environment. What is striking, however, is the overrepresentation of males in important life undertakings like work and studies.

\subsubsection{Who is active (the "protagonist") in the image?}

Apart from the images in collages (4 images) -which represent both genders as active participants, males were given precedence over females in active role performance. Males appeared as protagonists in 16 images (53.33\%), whereas, females took on this role only in 10 images (33.33\%). It is worth noting 
that in cases where females were cast as actors the characters in the images were teenagers. The shift to male protagonists, however, occurs with images portraying adults. Table 3 illustrates this point.

Table 3. Active role distribution according to age group and gender

\begin{tabular}{ccc}
\hline Active role & $n$ of adults & $n$ of teenagers \\
\hline Male & 14 & 2 \\
Female & 6 & 4 \\
\hline
\end{tabular}

The dominance of adult males in adopting the active role (doer) reflects the attitudes of the prevailing macho culture which asserts men's authority in society.

\subsubsection{Who is passive (the "receiver") in the image(s)?}

The results of image analysis for this question are in line with those reported in the previous one. Female characters were given a passive role in the majority of cases (16 images). They came into view as a goal of a male's action in 10 images and a reactor to an action (external or male initiated) in 6 images. When males were depicted in the position of the 'receiver', however, they seemed comfortable with this role which looks more important in the context of the image.

\subsubsection{Who has status in the image $(s)$ ?}

According to Giaschi (2000 p.39), "Status can be conferred by physical stature, by the perspective of the portrayer (in this case usually a photographer), by accessorization (clothing, desks, etc.), and by the degree to which others serve". Using Giaschi's criteria for judging, the status of females in the images altogether can be considered relatively lower than that of males. This low standing is especially notable in the textbook 'Getting Through' in which no single female appeared enjoying a high status in the presence of men. In the other two textbooks, however, the status gap between the two genders was not significant as shown in table 4 .

Table 4. The status of males and females in the images

\begin{tabular}{ccccccc}
\hline Textbook & \multicolumn{2}{c}{ At the Crossroads } & \multicolumn{2}{c}{ Getting Through } & \multicolumn{2}{c}{ New Prospects } \\
\hline Status & High & Low & High & Low & High & Low \\
Female & 4 & 5 & 0 & 5 & 6 & 5 \\
Male & 5 & 4 & 5 & 0 & 5 & 6 \\
\hline
\end{tabular}

The equal status between females and males within the latter textbooks was also achieved in collages which often contributed to reduce gender bias. A good example of these is the front cover of 'New Prospects' (image 16 in the appendix) which shows three women and three men all involved in specific tasks using some modern equipment like laptops, a telephone and a laboratory tube.

\subsubsection{What does the body language communicate?}

In order to establish a pattern that fits in the images of the textbooks, our analysis focused on body posture and facial expressions. It was assumed that these two facets of body language provide an indication of the possible meanings created by the characters' non-verbal behaviour in the majority of images (Analyzing cartoon strips for body language often proved challenging). The analysis showed that females adopted a good body posture as often as did males with the exception of one image in the textbook 'At the Crossroads' (see appendix, image 4). This image shows a man at an office seating himself comfortably on a swivel chair and engaging in a conversation with a woman (secretary) who seems listening attentively and taking notes. Her body posture (leaning against the computer screen), nevertheless, implies a kind of lenient attitude towards the man's authority. As far as facial expressions 
are concerned, the analysis indicated that in the overwhelming majority of images both males and females appeared with faces that express high self-worth and confidence. There are only two notable exceptions in the textbook 'Getting Through': One image was taken in the aftermath of an earthquake (image 14 in the appendix), and the other shows three pupils adopting some safety measures in case this natural disaster strikes again (image 15). As opposed to males who appeared bold and fearless in the face of calamities, females evinced clearly the inability to control their emotions in case something went wrong.

\subsubsection{What does the clothing communicate?}

In our examination of the corpus for this question, we excluded 2 images from the analysis given that they contain two female characters whose attire could hardly be seen (See appendix, image 6 and 12). The image analysis was initially carried out by counting the number of times that characters appeared wearing a specific type of clothing. Table 5 presents the major types of wear of both genders.

Table 5. Main types of wear of both genders

\begin{tabular}{cccc}
\hline Type of wear & Casual & Formal & Sport \\
\hline Male & 29 & 22 & 7 \\
Female & 21 & 19 & 6 \\
\hline
\end{tabular}

As the table above shows, both females and males appeared wearing casual clothes more times than formal and sport clothing. Apart from one image where two men and a woman were shown in shabby clothes, all the characters were suitably dressed. Moreover, both genders were displayed in a wide range of garments (uniforms, academic and ceremonial gowns, suits and head covers). In the overwhelming majority of cases, females appeared in modern as well as fashionable clothing styles, though less associated with the popular stereotype of physical attractiveness. They were also shown in sportswear to indicate, so to speak, that this activity is not confined only to males.

\subsubsection{Where are the eyes directed?}

Following Kress and van Leeuwen (2006), the image analysis was done with reference to the relationship between the represented characters and the viewer. These authors argue that when the characters look directly at the viewer, a demand for some kind of interaction is created. However, when they appear looking away from her/him, these characters become "objects of contemplation" (Kress \& van Leeuwen, 2006 p. 119), resulting in the absence of contact. The examination of gaze direction of both genders in the images revealed that the vast majority of characters appeared looking away from the viewer. The ratio of the characters looking at the viewer to those looking away from him/her is 1: 4.5. What is particularly notable, though, is the equal number of females and males who appeared directing their eyes towards the viewer (10 characters for each gender). As such, the sense of detachment with the viewer is by no means restricted to females alone. The careful consideration of the context of the images, though, reveals some discrepancies in the direct gaze across the two genders. While all the male characters seem to express self-confidence and assertion, some female characters ( 2 girls and a woman) manifested signs of fear and agony as though demanding rescue or help from the addressee (images 14 and 15 in the appendix).

\subsection{Teachers' perceptions of gender positioning within images}

Although the overriding aim of the teacher questionnaire was to tap on teachers' perceptions of gender bias within the visual discourse of the textbooks, exploring their teaching practices in terms of textbook use and evaluation was felt to be a prerequisite. Collecting information about these issues can presumably provide a clearer picture in the light of which the teachers' stated views will make more 
sense. The overall results of this part of the survey indicate that the majority of the teachers (80\%) use the textbook only in so far as it meets their learners' needs or fits their teaching style, and that many of them $(60 \%)$ often feel the need to supplement these textbooks with other materials.

By expressing their degree of agreement with the 09 items of the third part of the survey, the respondents reported the perceptions they held about gender positioning within the visual discourse of the three textbooks. Table 6 presents the main findings about this issue.

Table 6. Teachers' perceptions of gender positioning within visual discourse of the textbooks

\begin{tabular}{|c|c|c|c|c|c|}
\hline Statement & $\begin{array}{l}\text { Strongly } \\
\text { Disagree }\end{array}$ & Disagree & Unsure & Agree & $\begin{array}{r}\text { Strongly } \\
\text { Agree }\end{array}$ \\
\hline $\begin{array}{l}\text { 1. Women and girls are less visible than men and } \\
\text { boys in the images of the textbooks }\end{array}$ & $12 \%$ & $64 \%$ & $16 \%$ & $4 \%$ & $4 \%$ \\
\hline $\begin{array}{l}\text { 2. Most female characters are given passive roles and } \\
\text { activities within the images }\end{array}$ & $8 \%$ & $64 \%$ & $16 \%$ & $8 \%$ & $4 \%$ \\
\hline $\begin{array}{l}\text { 3. The occupations assigned to working women in } \\
\text { the images reflect the stereotypes of society }\end{array}$ & $8 \%$ & $48 \%$ & $20 \%$ & $24 \%$ & $0 \%$ \\
\hline $\begin{array}{l}\text { 4. Most images portray male characters as strong and } \\
\text { superior to females }\end{array}$ & $8 \%$ & $72 \%$ & $0 \%$ & $12 \%$ & $8 \%$ \\
\hline $\begin{array}{l}\text { 5. When shown together in images, female } \\
\text { characters are less apparent than males }\end{array}$ & $4 \%$ & $68 \%$ & $8 \%$ & $16 \%$ & $4 \%$ \\
\hline $\begin{array}{l}\text { 6. In most images, women and girls appear } \\
\text { dependent on men and boys }\end{array}$ & $4 \%$ & $56 \%$ & $12 \%$ & $20 \%$ & $8 \%$ \\
\hline $\begin{array}{l}\text { 7. Images of women having non-traditional jobs like } \\
\text { soldier or engineer are rare in the textbooks }\end{array}$ & $0 \%$ & $20 \%$ & $20 \%$ & $44 \%$ & $16 \%$ \\
\hline $\begin{array}{l}\text { 8. The images of the textbooks do not show women } \\
\text { engaging in a variety of jobs }\end{array}$ & $4 \%$ & $40 \%$ & $16 \%$ & $32 \%$ & $8 \%$ \\
\hline $\begin{array}{l}\text { 9. These images do not encourage intellectual and } \\
\text { personal growth of girls }\end{array}$ & $0 \%$ & $48 \%$ & $32 \%$ & $16 \%$ & $4 \%$ \\
\hline
\end{tabular}

The results in the table indicate clearly a trend towards teachers' objection against the existence of blatant gender discrimination within the visual discourse of the textbooks. As the figures show, all the elicited responses have clustered in the 'disagree' category, with the exception of statement 7 . The low disagreement percentage in this statement $(20 \%)$ is perhaps due to the respondents' focused attention on the first example of females' non-traditional jobs (soldier) in which no female character was in effect represented -unlike the ensuing example 'engineer'. Meanwhile, the item that received the highest percentage of disagreement is number 4, which concerns the portrayal of males as strong and superior to females. In contrast to all the other items, this was also the only one on which no respondent took a neutral position. Respondents have also shown considerable disagreement with statements 1,2 and 5 . In percentages terms -if the 'unsure' category is excluded in the latter items, the disagreement responses far exceed those of agreement. Similarly, the percentage of 'unsure' responses seems relatively high with statement 9 in comparison to the other ones. In fact, this result which reflects the teachers' undecided frame of mind about the negative impact of pictorial misrepresentation on females, is congruent with the inconclusive evidence about this issue as reported in the literature review.

In the fourth section of the questionnaire, the respondents were asked to write further comments about the topic of gender within the visual discourse of ELT materials. Although the question was optional, approximately half of the teachers (13) provided some relevant feedback. A recurrent theme within their comments (mentioned by 9 teachers) deals with the little importance of gender bias in 
materials especially when compared with the enormous challenges in EFL classrooms. In this respect, a teacher said that 'The problems in the classroom are many and we do not accord much importance to this issue'. Another theme that emerges from the respondents' comments (mentioned by 4 teachers) outlines the limited availability of visual discourse, particularly images, within the textbooks. This situation, according to them, restricts students' awareness of and discussion about gender representation. Overall, the comments made by teachers did not seem to be in harmony with their perceptions of gender positioning within the visual discourse of the textbooks as suggested by the questionnaire data.

\section{Discussion}

The current study was conducted to examine gender positioning within the visual discourse of three Algerian secondary school English textbooks. Additionally, it aimed at surveying a group of EFL teachers' perceptions of this issue which has been extensively explored in learning and teaching materials over the last few decades. It was believed that the inclusion of language teachers' interpretation of gender representation within the images of the three textbooks alongside an elaborate critical analysis serves to get a clearer picture about this delicate theme.

Overall, the results of the critical image analysis have shown both encouraging as well as disturbing signs of gender positioning in the visual discourse of the textbooks. As expected, the gender gap seems narrow in comparison to early studies which reported a large number of unmistakable cases of bias against females, such as clear exclusion or distorted portrayal (Hartman \& Judd, 1978; Hellinger, 1980; Porreca, 1984). To illustrate, images depicting adult females performing nontraditional tasks (as opposed to domestic chores or child rearing), though not so recurrent, were found throughout the three textbooks. This confirms Blumberg's (2008) assertion when she stated that "the most egregious and blatant examples of sexism seem to have disappeared or been muted" (Blumberg 2008 p.17), which is actually understandable if we take into account the considerable efforts made in the fight against gender bias in educational materials (Michel, 1986; Women in ELT materials, 1991). Actually, in the wake of the disappointing results that documented the tenacity and prevalence of discrimination against females, sensitivity to and awareness of the importance of gender equity within learning materials have dramatically increased.

The detailed scrutiny, however, reveals some gender imbalances which can hardly be ascribed to accidental occurrence. For example, male characters were not only more visible and active than females within the images but they were sometimes portrayed in a more privileged status that clearly carries biased messages. These findings are consistent with the bleak picture that similar previous studies depicted about gender representation within the three textbooks (Boukheddad, 2011; Lakhdar-Barka, 2011; Boubakour, 2017), suggesting that the more light is spot on gender representation in these materials, the more instances of embedded inequity are uncovered. Interestingly, this state of affairs confirms the multilayered and complex view about the nature of gender bias and discrimination in learning materials. While this inequitable representation could arguably be explained in unique-gender images, it can hardly be justified within visuals that represent females and males interacting with each other. The likelihood that such visuals carry an implicit message of males' dominance over females may well increase. Of course, there seems to be nothing wrong with a male taking the lead in a situation where female characters are present; nevertheless, the constant repetition of these scenes gives rise to suspicion about the intentions of the illustrators.

The critical analysis has also shown that in images where both genders are portrayed as equal there are some subtle nuances which can be understood as indications of males' precedence over females. This was clearly manifest in the findings about females' status, body language and gaze direction. 
Perhaps, the selected images with these subtleties were taken from some settings which reflect or adhere to some deeply-rooted traditional attitudes. Yet, despite these contextual constraints it seems safer, at least for educational purposes, to choose visuals that display both females and males equitably represented. Alternatively, the visuals that contain gender biases can be replaced by collages which technically allow for more freedom in image creation. Interestingly, the collage technique has been used in the three textbooks, though just sparingly. This use, however, suggests that the illustrators are cognizant of the importance of fair gender representation within learning materials.

The findings obtained from the teacher questionnaire indicate that teachers perceive gender positioning within the visual discourse in a different way. Contrary to the reported results of image analysis, the majority of teachers have a positive view about the pictorial representation of males and females in the textbooks. In fact, such perceptions can contribute to reduce or correct the biases in the materials as argued by Sunderland (2000). However, the examination of the comments elicited from some teachers at the end of the questionnaire reveals that this positive view could be plausibly attributed to a lack of awareness of the issue of gender positioning since it bears little relevance to their actual teaching concerns. This lack of interest in gender representation within ELT materials was also reported in a survey conducted by Aeginitou et al (as cited in Sunderland 2000). Although this survey was conducted nearly three decades ago, it can be reasonably expected that the issue of sexism and gender bias will continue to be of no concern to the majority of EFL teachers unless they are made aware of its possible negative outcomes.

Although the dialogic nature of Giaschi's (2000) critical image analysis has dissected the visual discourse in the three textbooks, the small corpus in our study prevented us from establishing patterns for the existing bias in the images. With a larger corpus, however, it may become possible to illuminate the specific aspects (for example clothes or body language) in which one gender experiences or suffers from injustices. Another limitation in the study is related to the size of the sample. The limited number of respondents cannot yield reasonably reliable data about a controversial issue such as gender bias. Finally, the data obtained from the teacher questionnaire was not detailed enough given that all the items in this instrument are closed-response questions. To gain more insights about teachers' perceptions of gender bias, it seems more feasible to rely on the interview which allows for gathering more accurate information.

\section{Conclusions}

The present study has highlighted the importance of investigating gender bias in learning materials through two different research instruments: a critical analytical framework and a teacher questionnaire. Despite the continued relevance of evaluating learning materials for sexism and gender bias, research that probes into how teachers and learners make sense of these discriminatory practices should be brought to the forefront. Studies of this kind may possibly produce conclusive evidence which supports the negative influence of biased materials on learners' academic achievements or their sense of identity.

Throughout the process of analyzing the images of the textbooks, it has been noticed that serious attempts were made to avoid gender bias while representing males and females. In order to increase the likelihood of the learners paying attention to this endeavour, topics about gender discrimination should be included in the textbooks, even within broader themes like intercultural communication. It is only through group discussions that learners can become fully aware of this issue and interact with all types of discourses in a way that is empowering rather than indoctrinating. With the phenomenal spread of internet use in recent years, it has become much harder to curb the harmful effects of materials flooding 
from different sources. Consequently, raising students' consciousness on issues of gender bias and misrepresentation, particularly in the visual mode of communication, is more needed than ever before.

The role played by the teacher in helping learners adopt a critical attitude towards gender representation is of capital importance. It is hardly surprising that many language teachers find this issue somewhat irrelevant to them given that they spend huge amounts of time on direct teaching responsibilities. These views, however, can easily be challenged if these teachers are directed to reflect on some of their usual practices with learners, which can be unintentionally discriminatory in nature. This heightened awareness of one's own practices can be transformed into a critical eye that discerns different forms of gender bias.

\section{References}

Abdelhay, B., \& Benhaddouche, W. (2015). Gender Stereotyping through Textbook Illustrations: A Case Study of Algerian Middle School Textbook-Spotlight on English. Mediterranean Journal of Social Sciences, 6(5), 435-440. DOI: 10.5901/mjss.2015.v6n5p435

Abolaji, M. S. (2013). Gender and Language Education Research: A Review. Journal of Language Teaching \& Research, 4(3), 454-463. DOI:10.4304/jltr.4.3.454-463

Ansari, H., \& Babaii, E. (2003). On the manifestation of subliminal sexism in current Iranian secondary school ELT textbooks. Iranian Journal of Applied Linguistics, 6(1), 40-56. Retrieved from http://www.sid.ir/En/Journal/ViewPaper.aspx?ID=4483

Bailey, B. L., Scantlebury, K., \& Letts, W. J. (1997). It's not my style: Using disclaimers to ignore gender issues in science. Journal of Teacher Education, 48(1), 29-36. https://doi.org/10.1177/0022487197048001005

Blumberg, R. L. (2008). The Invisible Obstacle to Educational Equity: Gender Bias in Textbooks. Prospects, 38, 345-361. https://doi.org/10.1007/s11125-009-9086-1

Boubakour, S. (2017). Femme et genre au prisme des manuels scolaires. Nouveaux Imaginaires $d u$ Féminin. Retrieved from https://hal.univ-cotedazur.fr/hal-01666786/document

Boukheddad, C. (2011). Gender, Race and Generation in Algerian Secondary School Textbooks (Magister dissertation). Retrieved from https://dl.ummto.dz/handle/ummto/199

Brugeilles, C. \& Cromer, S. (2009). Analysing gender representations in school textbooks. Paris: UMR CEPED.

Cook, M. (2005). Gender bias in language textbooks. Journal of the Faculty of Global Communication, Siebold University of Nagasaki, 6, 13-18. Retrieved from http://hdl.handle.net/10561/284

Cook, M. (2015). Gender Bias in ESL/EFL Textbooks: 10 Years Later. JALT Materials Writers SIG, 23 (3), 4-7. Retrieved from http://materialswriters.org/joomla/index.php/83-articles/148-btkarchives

Demir, Y., \& Yavuz, M. (2017). Do ELT coursebooks still suffer from gender inequalities? A case study from Turkey. Journal of Language and Linguistic Studies, 13(1), 103-122.

Donaghy, K., \& Xerri, D. (Eds.). (2017). The image in English language teaching. Malta: ELT Council. Retrieved from http://kierandonaghy.com/books/image-english-language-teaching/ 
Fairclough, N. (1989). Language and power. London: Longman.

Giaschi, P. (2000). Gender positioning in education: A critical image analysis of ESL texts. TESL Canada Journal, 18(1), 32-46. https://doi.org/10.18806/tesl.v18i1.898

Graci, J. P. (1989). Are Foreign Language Textbooks Sexist? An Exploration of Modes of Evaluation. Foreign Language Annals, 22(5), 477-486. https://doi.org/10.1111/j.1944-9720.1989.tb02771.x

Gray, J. (2002). The global coursebook in English language teaching. In D. Block \& D. Cameron (Eds.), Globalization and language teaching (pp. 161-177). New York: Routledge.

Gunther, K., \& Leeuwen, T.V. (2006). Reading images: The grammar of visual design. (2 ${ }^{\text {nd }}$ ed.). New York: Taylor and Francis e-library.

Gupta, A. F., \& Yin, A. L. S. (1990). Gender representation in English language textbooks used in the Singapore primary schools. Language and education, 4(1), 29-50. https://doi.org/10.1080/09500789009541271

Hartman, P. \& Judd, E. (1978). Sexism and TESOL materials. TESOL Quarterly, 12(4), 383-393. DOI: $10.2307 / 3586137$

Hellinger, M. (1980). 'For men must work, and women must weep': Sexism in English language textbooks used in German schools. Women's Studies International Quarterly, 3(2-3), 267-275. https://doi.org/10.1016/S0148-0685(80)92323-4

Jones, M. A., Kitetu, C., \& Sunderland, J. (1997). Discourse roles, gender and language textbook dialogues: who learns what from John and Sally? Gender and Education, 9(4), 469-490. https://doi.org/10.1080/09540259721204

Kobia, J. M. (2009). Femininity and masculinity in English primary school textbooks in Kenya. The International Journal of Language Society and Culture, 28, 57-71. Retrieved from https://aaref.com.au/wp-content/uploads/2018/05/28-6.pdf

Lakhdar-Barka, F. (2011). La représentation du personnage féminin dans le manuel d'Anglais en Algérie: vers une éclipse totale? Tréma, (35-36), 114-127. DOI: 10.4000/trema.2634

Lakoff, R. (1975). Language and women's place. New York: Harper and Row Publishers.

Lee, J. F. (2014). Gender representation in Hong Kong primary school ELT textbooks-a comparative study. Gender and Education, 26(4), 356-376. https://doi.org/10.1080/09540253.2014.916400

Lee, J. F. \& Collins, P. (2008). Gender Voices in Hong Kong English Textbooks-Some Past and Current Practices. Sex Roles. 59(1-2), 127-137. https://doi.org/10.1007/s11199-008-9414-6

Levine, D., \& O'Sullivan, M. (2010). Gender and images in the EFL textbook Talk a lot, Starter Book. The Journal and Proceedings of GALE, 3, 33-42. Retrieved from

https://gale-sig.org/website/galejournalv3.pdf

Lesikin, J. (2001). Determining Social Prominence: A Methodology for Uncovering Gender Bias in ESL Textbooks. In A. Hewings \& H. D. Hall (Eds.), Innovation in English Language Teaching: A Reader. (pp. 275-283). New York: Routledge.

Littlejohn, A., \& Windeatt, S. (1989). Beyond language learning: perspectives on materials design. In R. K. Johnson (Ed.), The second language curriculum. Cambridge: Cambridge University Press.

Ma, K. (1998). The representation of gender in current ESL reading materials. The ORTESOL Journal, $19,1-22$. 
Michel, A. (1986). Down with Stereotypes! Eliminating Sexism from Children's Literature and School Textbooks. Paris, France: UNESCO.

Mills, S., \& Abolaji, S. M. (Eds.). (2015). Gender Representation in Learning Materials: International Perspectives. New York, Routledge.

Mineshima, M. (2008). Gender representations in an EFL textbook. Bulletin of Niigata Institute of Technology, 13, 121-140. Retrieved from http://hdl.handle.net/10623/20259

Porreca, K.L. (1984). Sexism in Current ESL Textbooks. TESOL Quarterly, 18(4), 705-724. https://doi.org/10.2307/3586584

Renner, C. E. (1997). Women are" Busy, Tall, and Beautiful": Looking at Sexism in EFL Materials. Retrieved from ERIC database. (ED411670).

Rifkin, B. (1998). Gender representation in foreign language textbooks: A case study of textbooks of Russian. The Modern Language Journal, 82(2), 217-236.

https://doi.org/10.1111/j.1540-4781.1998.tb01195.x

Sadker, D. (1999). Gender equity: Still knocking at the classroom door. Educational Leadership, 56(7), 22-27.

Sadker, D. M., \& Zittleman, K. (2007). Practical strategies for detecting and correcting gender bias in your classroom. Gender in the classroom: Foundations, skills, methods, and strategies across the curriculum. In J. A. Banks \& C. A. McGee Banks (Eds.). Multicultural Education: Issues and Perspectives. (pp. 137-153). New Jersey, USA: John Wiley \& Sons, Inc.

Sakita, T. I. (1995). Sexism in Japanese English education: A survey of EFL texts. Women and Language, 13(2), 5. Questia, web, 05, April 2018.

Sunderland, J. (1992). Gender in the EFL classroom. ELT Journal, 46(1), 81-91. https://doi.org/10.1093/elt/46.1.81

Sunderland, J. (2000). New Understanding of Gender and Language Classroom Research: texts, teachers and student talk. Language Teaching Research, 4(2), 149-173. https://doi.org/10.1177/136216880000400204

Sunderland, J. (2015). Gender (Representation) in Foreign Language Textbooks: Avoiding Pitfalls and Moving On. In S. Mills \& M. S. Abolaji (Eds.). Gender Representation in Learning Materials: International Perspectives. (pp. 19-34). New York: Routledge.

UNFPA (1994). Issue 7: Women Empowerment. Cairo: UNFPA. Retrieved from https://www.unfpa.org/fr/node/9551

Wodak, R (2002). What CDA is about - a summary of its history, important concepts and its developments. In R. Wodak \& M. Meyer (Eds.). Methods of critical discourse analysis (pp. 1-13). London: Sage Publications, Ltd.

Women in EFL Materials (1991). On balance: guidelines for the representation of women and men in English language teaching materials. Retrieved from https://libcom.org/blog/balance-guidelinesrepresentation-women-men-english-language-teaching-materials-28052014

Zerar, S., \& Riche, B. (2014). Of the Representation of Women in the Algerian Textbooks of English. Humanities and Social Sciences Review, 3(4), 33-41. Retrieved from http://www.universitypublications.net/hssr/0304/html/B4R466.xml 


\section{Appendix A.}

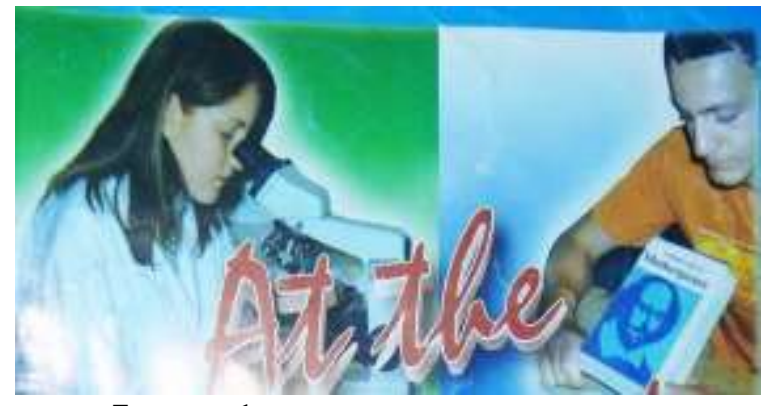

Image 1

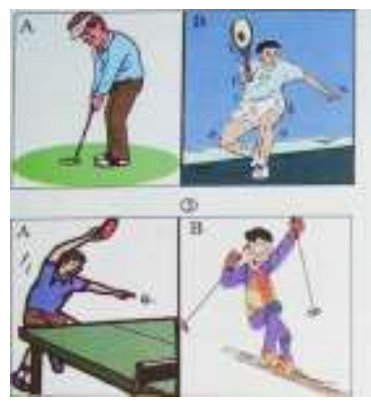

Image 3

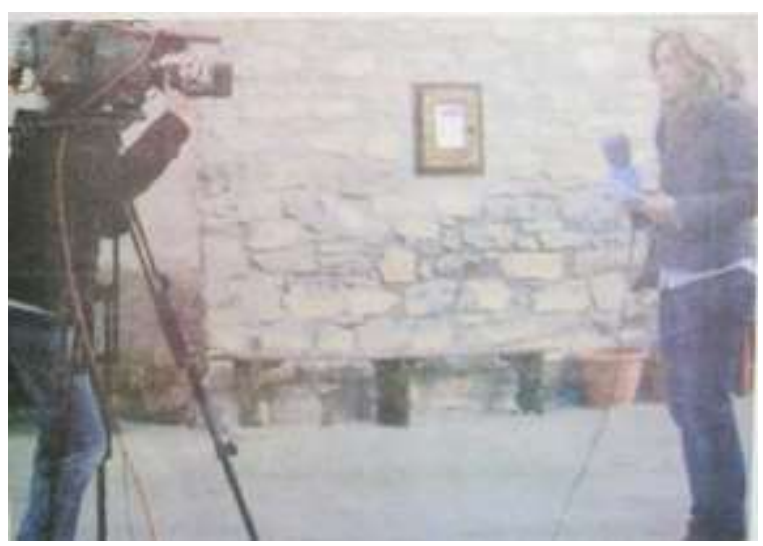

Image 5

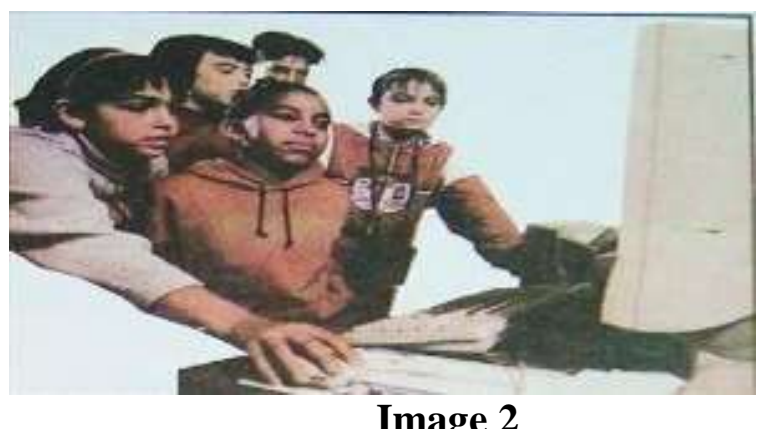

Image 2

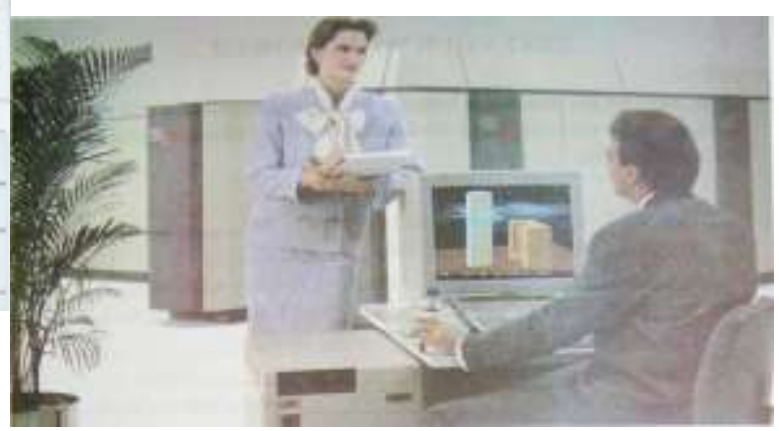

Image 4

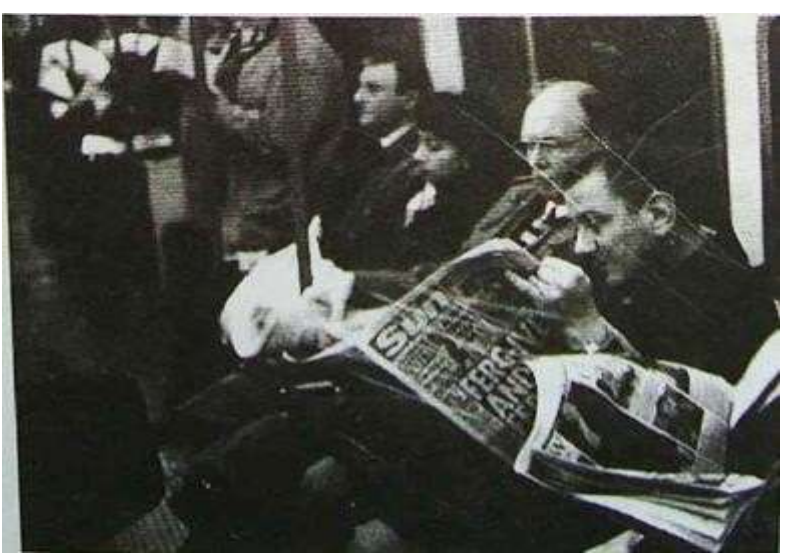

Image 6 


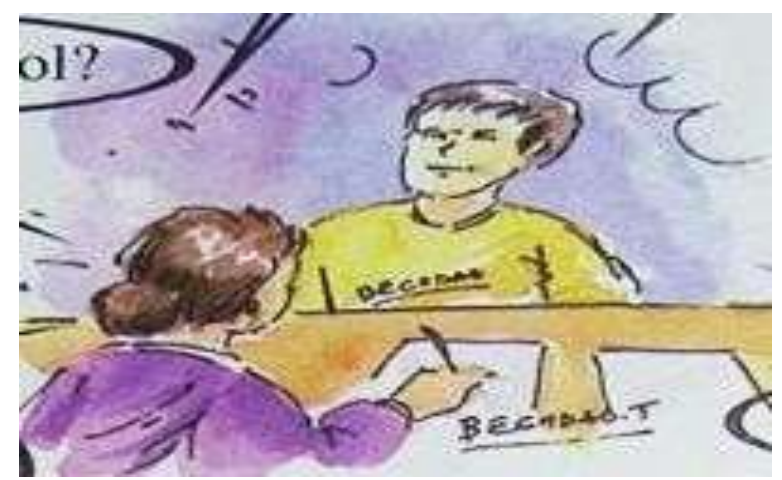

Image 7

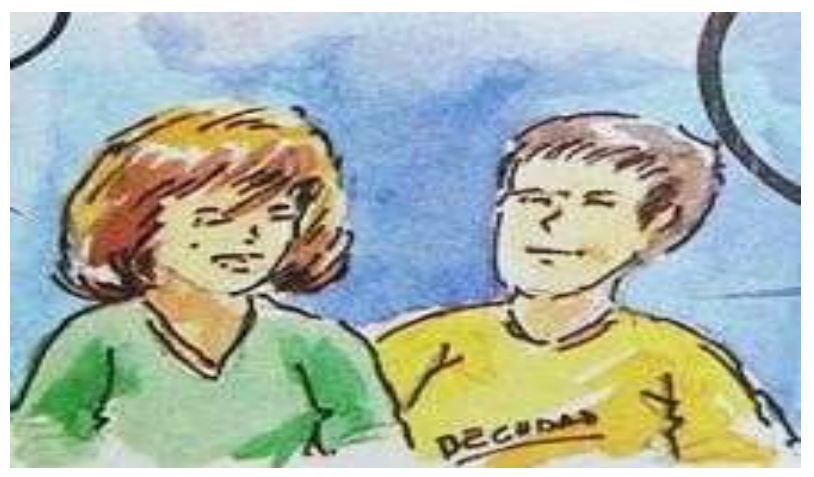

Image 8

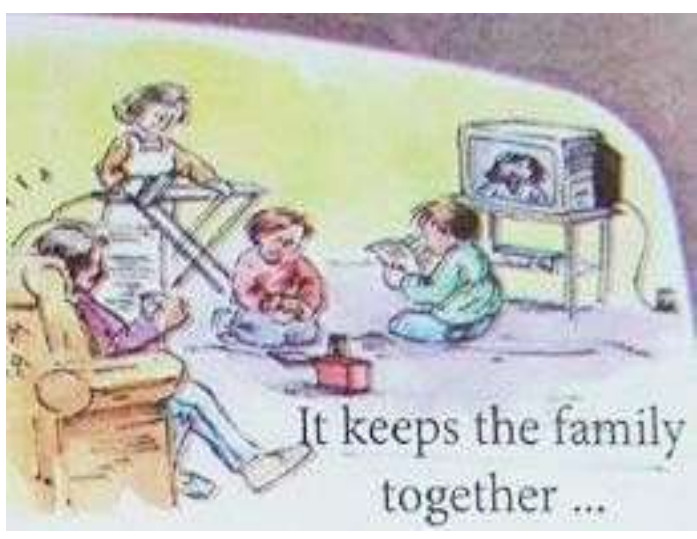

Image 9

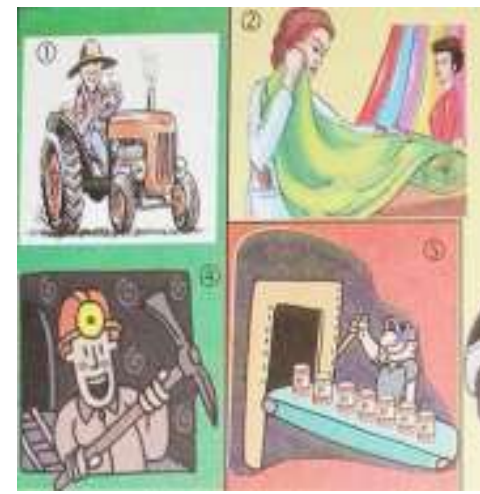

Image 11

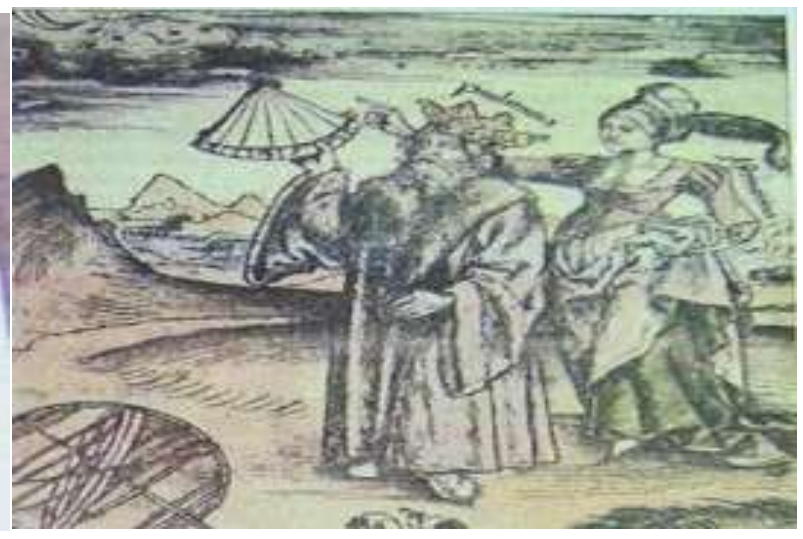

Image 10

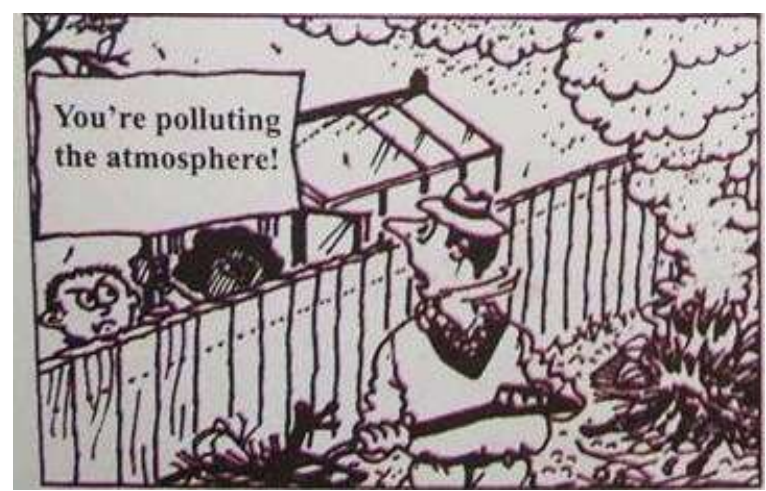

Image 12 


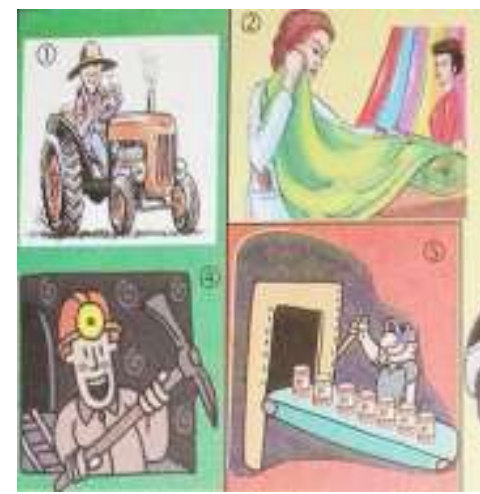

Image 13

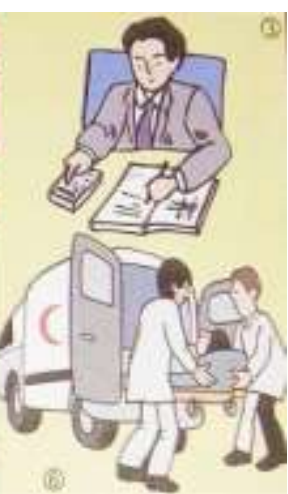

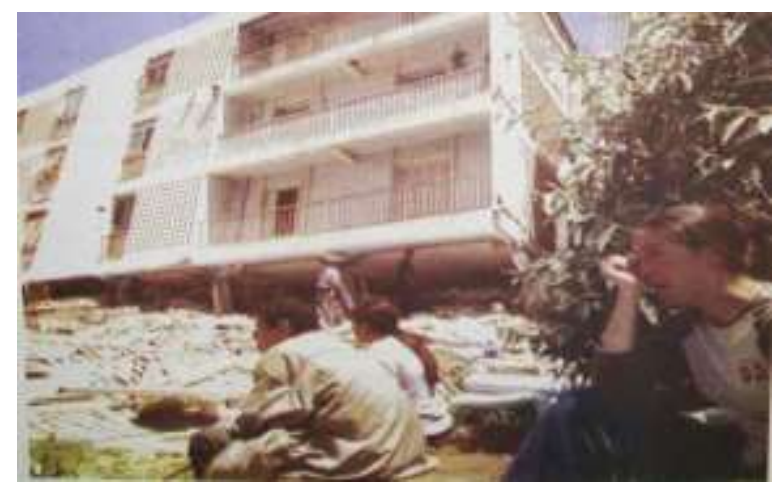

Image 14

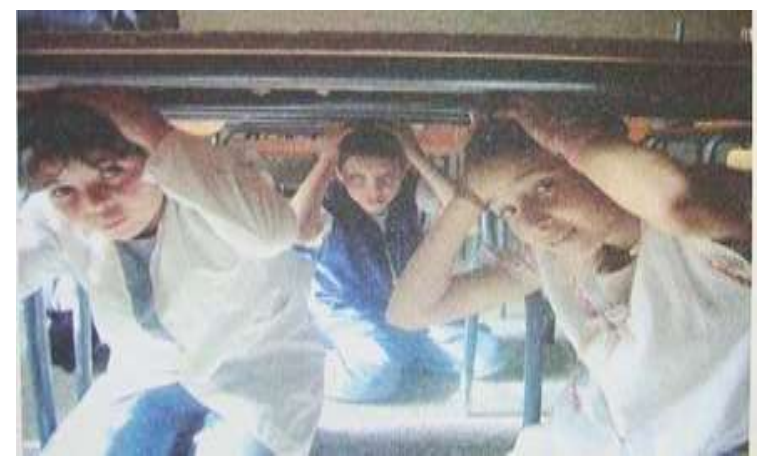

Image 15

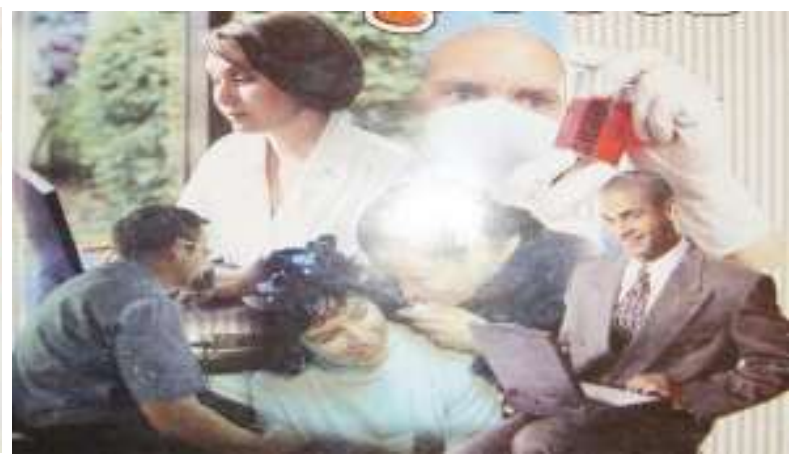

Image 16

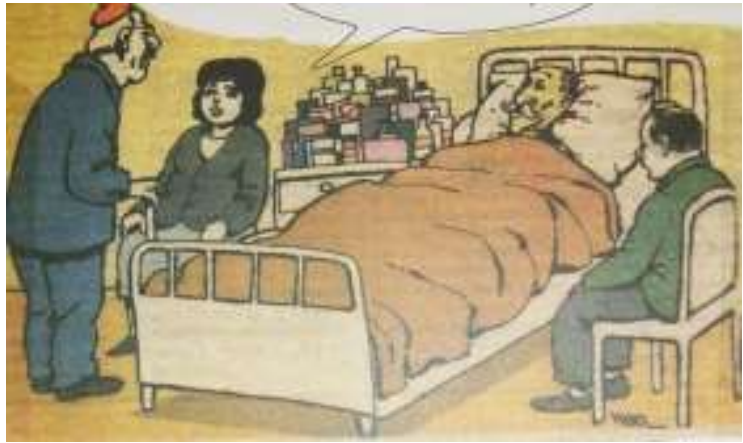

Image 17

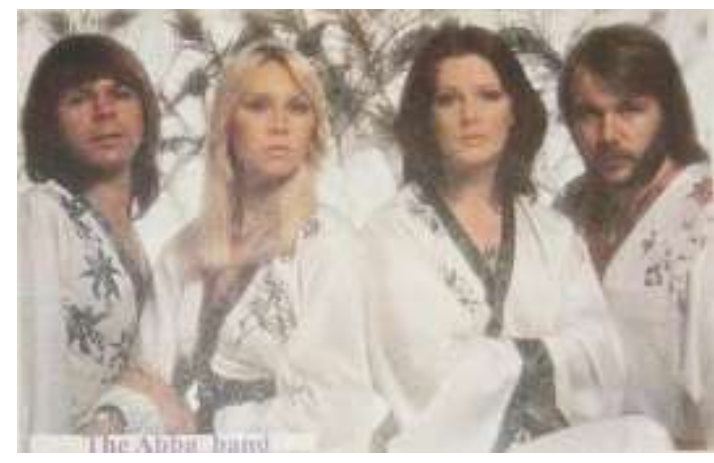

Image 19

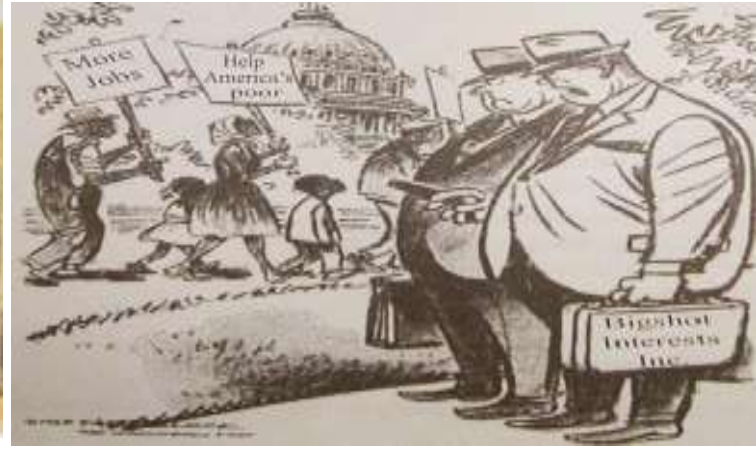

Image 18

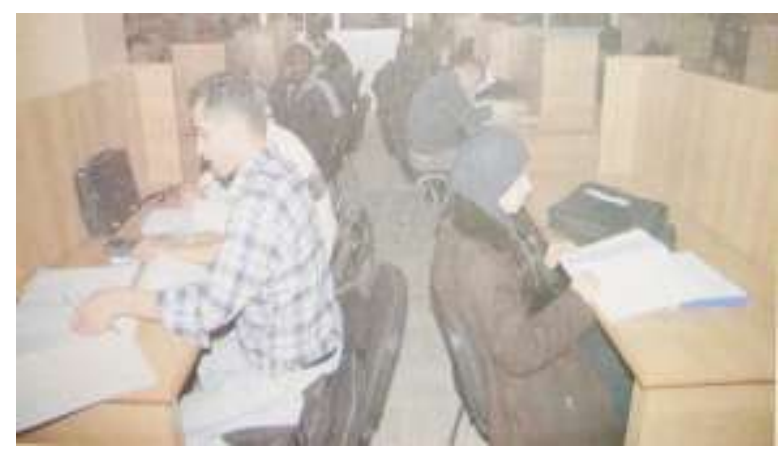

Image 20 


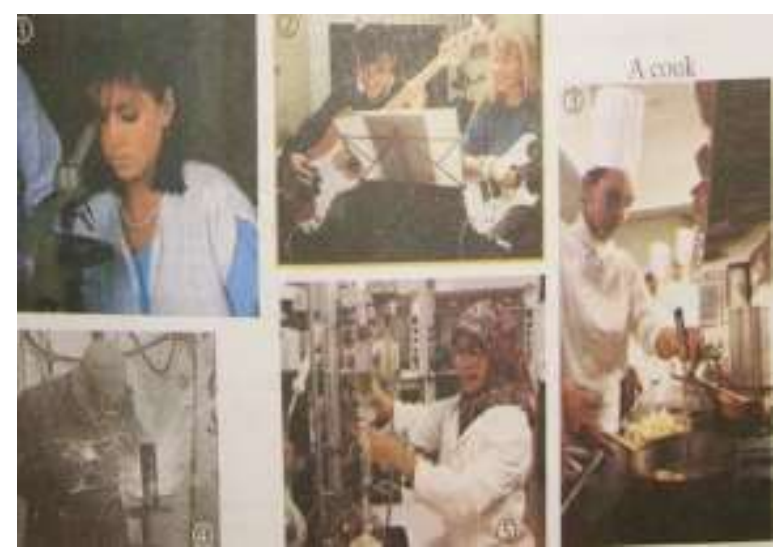

Image 21

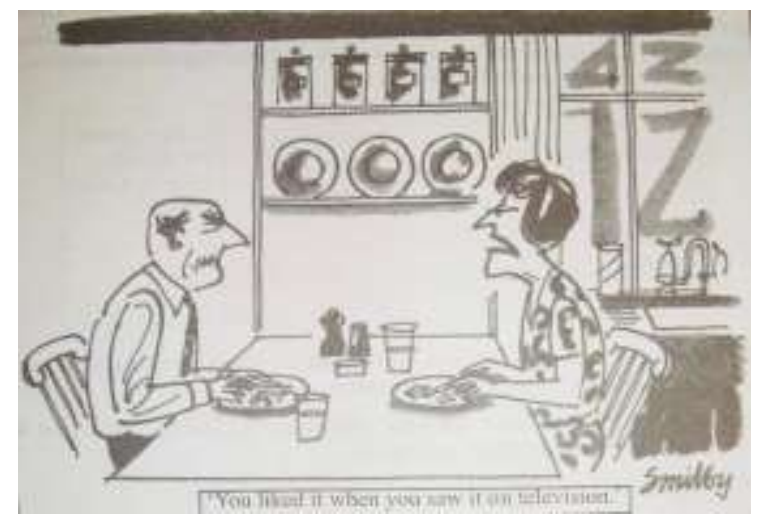

Image 23

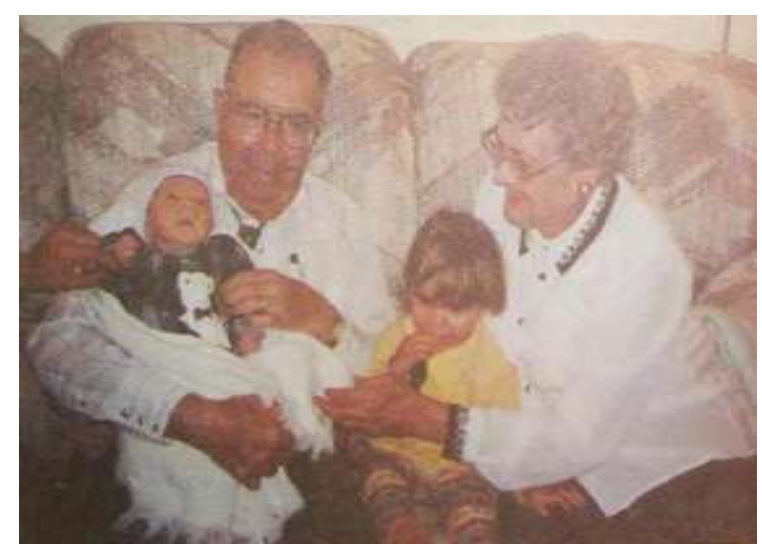

Image $\mathbf{2 5}$

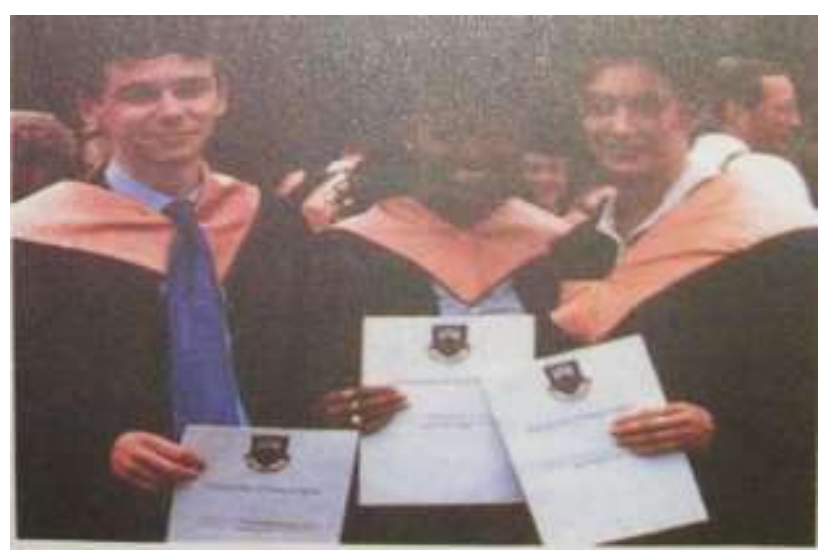

Image 22

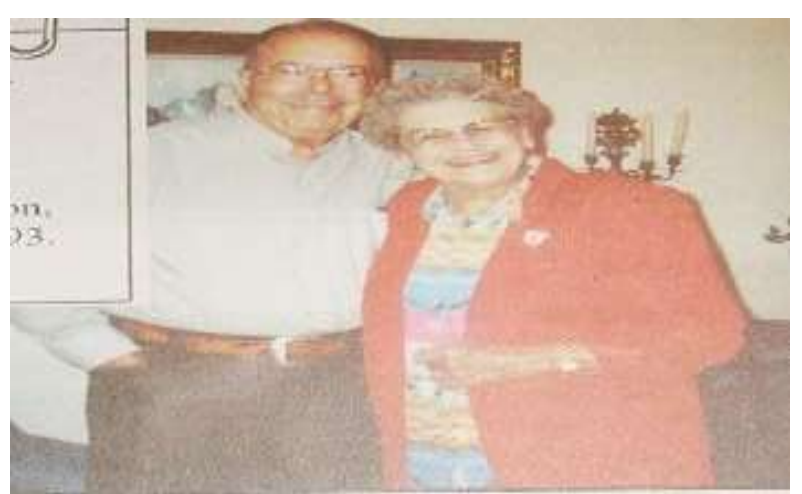

Image 24

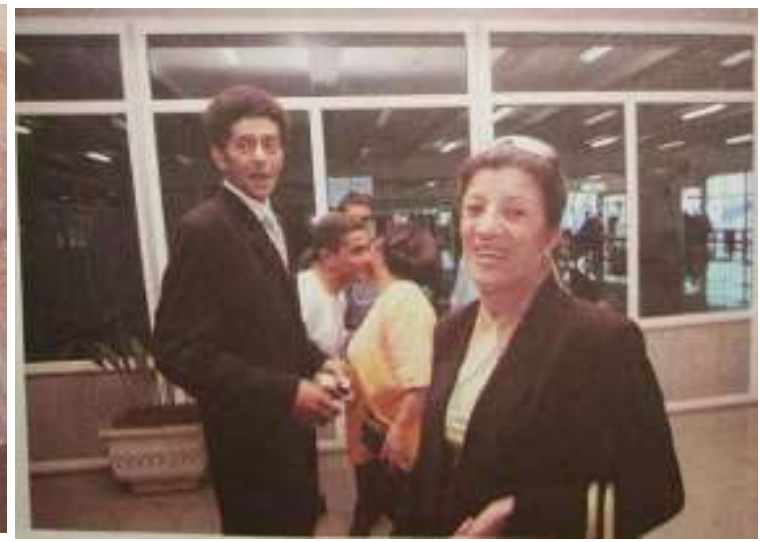

Image 26 


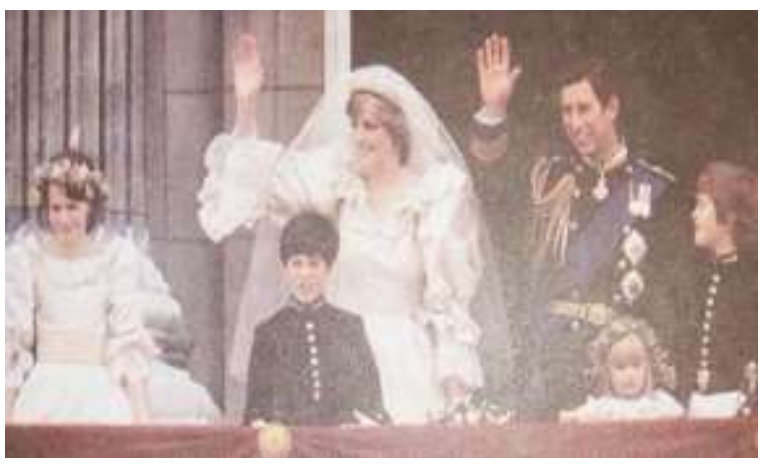

Image 27

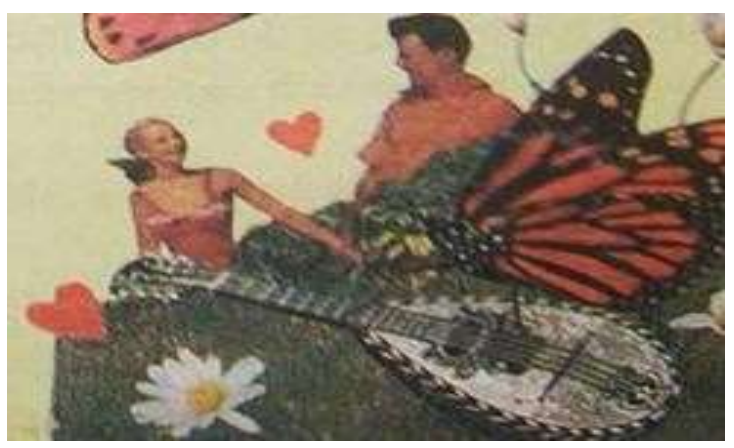

Image 28

\section{Cezayir ortaöğretiminin EFL ders kitaplarının görsel söyleminde cinsiyet konumlandırması: Öğretmenlerin algılarına karşı eleştirel imaj analizi}

\section{$\ddot{O} \mathbf{z}$}

Bu çalışma, üç Cezayirli orta öğretim İngilizce ders kitabının görsel söyleminde toplumsal cinsiyet konumlandırma konusunu gözden geçirmektedir. Cinsiyet temsili hakkında bilgilendirilmiş bir görüş elde etmek için, bu materyaller, teorik eleştirel hesapların sonuçlarını, dil öğretmenlerinin ders kitaplarındaki cinsiyet yanlılı̆̆ konusundaki potansiyel yorumlarıla birleştirmenin gerekli olduğu kabul edildi. İlk olarak, seçilen görsel korpus, kritik görüntü analizi ile cinsiyet yanlılığı açısından incelenmiştir. Cinsiyet önyargısının içine alınabileceği ana yönler, iyi hazırlanmış bir çerçevede ele alınmıştır. İkincisi, ortaöğretim EFL öğretmenlerinin algıları, uygun bir şekilde seçilmiş bir örneğe gönderilen bir öz bildirim anketi ile incelenmiştir. Sonuçların karşılaştırmalı analizi,görüntülerin çoğunluğunun kadınlara karşı önyargının net belirtileri olmasına rağmen, çoğu öğretmenin, görsel temsil söz konusu olduğunda, iki cinsiyet arasındaki dengesizlikleri görmenin zor olduğunu göstermektedir. $\mathrm{Bu}$ uyumsuzluk, cinsiyet yanlılığının halen EFL dil pratisyenlerinin çoğunluğu tarafından büyük bir ilgi alanı olarak görülmesi gerçeğiyle tartı̧malı görünmektedir.

Anahtar sözcükler: cinsiyet konumlandırma; cinsiyet yanlılı̆ı; görsel söylem; EFL öğretmenlerinin algıları; ELT ders kitapları.

\section{AUTHOR BIODATA}

Khalid Ziad is an associate professor at the department of foreign languages at A. Boussouf University Centre in Algeria. He is currently pursuing his Phd research in applied linguistics within the research area of language materials evaluation and design. His research interests include also discourse analysis, syllabus design and psycholinguistics.

Ghania Ouahmiche is a professor at the department of foreign languages at Oran 2 university in Algeria. She holds a PhD in Foreign Language Teaching and Language Sciences (French language and Francophone literature) and a Phd in sociolinguistics and language planning (English Language). Her research interests include but limited to: foreign language teaching methodology, sociolinguistic variation, language policy and planning. 